\title{
STUDI KOMPARASI MENGGUNAKAN MODEL IBL DAN POGIL TERHADAP PRESTASI BELAJAR SISWA DITINJAU DARI KETERAMPILAN PROSES
}

\author{
Ida Madyani, Haryono*, dan Suryadi Budi Utomo \\ Program Studi Pendidikan Kimia, FKIP,Universitas Sebelas Maret, Surakarta, Indonesia \\ “Keperluan korespondensi, HP 08122624628, e-mail: hharyono52@yahoo.com
}

\begin{abstract}
ABSTRAK
Penelitian ini bertujuan untuk: (1) mengetahui perbedaan prestasi belajar siswa yang menggunakan model pembelajaran IBL dan POGIL; (2) mengetahui perbedaan prestasi belajar pada siswa yang memiliki keterampilan proses tinggi dan keterampilan proses rendah; dan (3) interaksi antara model pembelajaran IBL dan POGIL dengan keterampilan proses terhadap prestasi belajar siswa. Penelitian ini merupakan penelitian kuantitatif dengan metode eksperimen. Sampel terdiri dari 2 kelas yang diambil menggunakan teknik cluster random sampling. Teknik pengumpulan data dalam penelitian ini yaitu tes tertulis, tes keterampilan proses, angket untuk penilaian afektif, dan observasi keterampilan praktikum untuk penilaian psikomotor. Uji hipotesis dalam penelitian ini menggunakan Analisis Varian (Anava) dua jalan dengan desain faktorial 2x2. Statistik uji menggunakan GLM (General Linier Model) yang terdapat dalam software SPSS 21 dengan taraf signifikansi $5 \%$. Berdasarkan hasil penelitian pada materi larutan penyangga kelas XI IPA SMA Negeri Kebakkramat tahun pelajaran 2016/2017 dapat disimpulkan : 1) Terdapat perbedaan prestasi belajar siswa pada aspek kognitif dan afektif menggunakan model pembelajaran Inquiry Based Learning (IBL) dan Process Oriented Guided Inquiry Learning (POGIL) sedangkan psikomotor tidak; (2) Terdapat perbedaan prestasi belajar siswa pada aspek afektif dan psikomotor pada siswa yang memiliki keterampilan proses tinggi dan keterampilan proses rendah, sedangkan kognitif tidak; dan (3) Terdapat interaksi antara model pembelajaran Inquiry Based Learning (IBL) dan Process Oriented Guided Inquiry Learning (POGIL) dengan keterampilan proses siswa terhadap prestasi belajar siswa aspek psikomotor sedangkan aspek kognitif dan afektif tidak.
\end{abstract}

Kata kunci: IBL, POGIL, Keterampilan Proses, Prestasi Belajar, Metode Eksperimen

\section{PENDAHULUAN}

Pendidikan merupakan bagian penting dalam suatu bangsa, tidak terkecuali bangsa Indonesia. Dengan sistem pendidikan yang baik diharapkan mampu melahirkan generasi penerus yang dapat membanggakan bangsa. Salah satu upaya dalam perbaikan sistem pendidikan nasional yang dilakukan oleh pemerintah adalah perbaikan kurikulum. Kurikulum Tingkat Satuan Pendidikan (KTSP) sebenarnya bukan merupakan kurikulum baru melainkan penyempurnaan kurikulum yang dicoba untuk diperkenalkan sebelumnya, yaitu "Kurikulum 2004" atau "Kurikulum Berbasis Kompetensi".

Mata pelajaran kimia di dalam Kurikulum Tingkat Satuan Pendidikan
(KTSP) bertujuan untuk menuntut siswa aktif membangun pengetahuannya, dan guru lebih berperan sebagai fasilitator dalam pembelajaran. Kompetensi yang diharapkan dicapai oleh siswa bukan hanya dalam aspek kognitif, melainkan aspek psikomotor dan afektif. Fakta di lapangan memperlihatkan bahwa dalam mempelajari sains, siswa cenderung lebih menghafal konsep, teori, dan prinsip tanpa memaknai proses perolehannya [1].

Keterampilan yang sangat sesuai dalam mempelajari ilmu kimia adalah keterampilan proses sains. Keterampilan proses sains adalah kemampuan berpikir yang digunakan ilmuan untuk membangun pengetahuan dalam upaya memecahkan masalah dan merumuskan hasilnya [2]. Pengembangan keterampilan proses 
sains yang membangun ilmu kimia antara lain: mengobservasi, menglasifikasi, memprediksi, mengukur, menyimpulkan, dan mengomunikasikan [3]. Keterampilan proses sains dibedakan menjadi 2 kelompok yaitu keterampilan proses dasar (basic skills) dan keterampilan proses terintegrasi (integrated skills) [4].

Materi dalam pembelajaran kimia yang sulit dipahami siswa salah satunya adalah larutan penyangga. Hal tersebut, didukung oleh hasil penelitian yang dilakukan oleh Marsita, mengenai kesulitan belajar siswa dalam memahami konsep materi larutan penyangga yang tidak dalam. Hal ini dapat teratasi dengan menghubungkan konsep larutan penyangga dengan kehidupan sehari-hari [5].

Sejalan dengan hal tersebut menurut Assriyanto, larutan penyangga merupakan salah satu materi dalam pembelajaran kimia yang meliputi sub-sub materi yakni: Komposisi Larutan Penyangga, $\mathrm{pH}$ Larutan Penyangga, Prinsip Kerja Larutan Penyangga dan Larutan Penyangga dalam Kehidupan Sehari-hari. Materi larutan penyangga memerlukan pemahaman sehingga siswa diharapkan dapat menggunakan pola pikir yang terstruktur, sistematis melalui tahap-tahap pemecahan yang tepat dan aktif terlibat secara langsung dalam memahami konsep. Apabila siswa kurang menguasai konsep yang ada, menyebabkan siswa akan mengalami kesulitan untuk menyelesaikan soal-soal yang merupakan aplikasi dari konsep pada larutan penyangga [6].

Salah satu cara untuk mencapai tujuan mata pelajaran kimia dalam KTSP dapat dilakukan dengan inquiry. Penggunaan model inkuiri dapat meningkatkan pembelajaran kimia [7]. Proses inkuiri bertujuan menumbuhkan kemampuan berpikir, bekerja dan bersikap ilmiah serta berkomunikasi sebagai salah satu aspek penting kecakapan hidup [8].

Model pembelajaran yang dipilih pada penelitian ini adalah model pembelajaran yang berbasis inquiry yakni Inquiry Based Learning (IBL) dan Process Oriented Guided Inquiry Learning (POGIL). Kedua model tersebut mengutamakan penyelidikan dalam menemukan konsep pada proses pembelajaran sehingga berpusat pada aktivitas siswa (student-centered). Pembelajaran inkuiri adalah rangkaian kegiatan pembelajaran yang menekankan pada proses berpikir secara kritis dan analitis untuk mencari dan menemukan sendiri jawaban dari suatu masalah yang dipertanyakan [9].

Sintaks atau fase-fase pelaksanaan model IBL dan POGIL pada dasarnya sama karena IBL dan POGIl termasuk tipe-tipe dari model inkuiri. Perbedaan keduanya terletak dari pelaksanaan dalam pembelajaran. Jika Inquiry Based Learning (1BL) diberi sedikit arahan dari guru, maka Process Oriented Guided Inquiry Learning (POGIL) mendapat lebih banyak arahan dari guru [10].

Pembelajaran dengan pendekatan IBL selalu mengusahakan agar siswa aktif secara mental maupun fisik. Materi yang disajikan guru bukan begitu saja diberitahukan dan diterima oleh siswa, tetapi siswa diusahakan sedemikian rupa sehingga mereka memperoleh berbagai pengalaman dalam rangka "menemukan sendiri" konsep-konsep yang direncanakan oleh guru [11].

IBL mempunyai ciri utama yakni menekankan kepada aktivitas siswa untuk mencari dan menemukan jawaban sendiri dari sesuatu yang dipertanyakan sehingga dapat mengembangkan potensi yang dimilikinya seperti berpikir secara sistematis, logis dan kritis [7]. POGIL merupakan penyempurnaan dari inkuiri terbimbing yang merupakan salah satu jenis inkuiri [4]. Penelitian yang dilakukan Widyaningsih (2012), model pembelajaran POGIL membuat siswa lebih terarah dalam menentukan pemecahan masalah yang menghasilkan konsep baru bagi siswa [12].

Dalam penelitian ini, tidak semua pendekatan keterampilan proses di gunakan. Hal tersebut disesuaikan dengan model yang digunakan dalam penelitian ini. Berdasarkan model POGIL dan IBL keterampilan dasar dalam keterampilan proses yang digunakan antara lain: (1) keterampilan mengobservasi atau mengamati, (2) keterampilan menghitung, (3) keterampilan mengukur, (4) keterampilan mengklasifikasi, (5) keterampilan membuat hipotesis, (6) keterampilan merencanakan penelitian/ eksperimen, (7) keterampilan menginterpretasi atau 
menafsirkan data, (8) keterampilan menyusun kesimpulan sementara, serta, (9) keterampilan meramalkan, keterampilan mengkomunikasikan.

Faktor-faktor yang mempengaruhi keberhasilan prestasi belajar siswa yang di teliti dalam penelitian ini antara lain model pembelajaran dan keterampilan proses. Dalam hal ini, model pembelajaran merupakan salah satu contoh dari faktor eksternal, sedangkan keterampilan proses merupakan faktor internal yang mempengaruhi keberhasilan prestasi belajar siswa. Faktor internal merupakan faktor yang berasal dari dalam diri siswa, sedangkan faktor eksternal merupakan faktor yang berasal dari luar diri siswa.

Pemilihan model dan penggunaan keterampilan proses harus disesuaikan dengan karakteristik peserta didik, materi dan sumber daya yang ada. Dengan demikian, diharapkan guru dapat menyampaikan pembelajaran kimia dengan lebih interaktif, menarik serta menyenangkan bagi siswa, sehingga akan mempengaruhi prestasi belajar siswa. Namun kenyataannya, banyak guru yang masih menggunakan metode konvensional yakni ceramah sehingga membuat siswa pasif, bahkan cenderung kurang berminat dalam mengikuti pembelajaran, akibatnya prestasi belajar kurang maksimal

Berdasarkan penjelasan di atas, materi larutan penyangga sesuai apabila di implementasikan menggunakan model pembelajaran Inquiry Based Learning (IBL) dan Process Oriented Guided Inquiry Learning (POGIL) yang melibatkan keterampilan proses sains di dalamnya.

\section{METODE PENELITIAN}

Penelitian ini dilaksanakan di SMA Negeri Kebakkramat kelas XI IPA pada semester genap tahun pelajaran 2016/2017. Rancangan penelitian ini adalah dengan menggunakan metode eksperimen yang bertujuan untuk mengetahui perbedaan penggunaan model pembelajaran Inquiry Based Learning (IBL) dan Process Oriented Guided Inquiry Learning (POGIL) yang ditinjau dari keterampilan proses siswa.
Uji hipotesis dalam penelitian ini menggunakan Analisis Varian (Anava) dua jalan dengan desain faktorial 2x2. Statistik uji menggunakan GLM (General Linier Model yang terdapat dalam software SPSS 21 dengan taraf signifikansi $5 \%$.

Tabel 1. Desain Faktorial Rancangan Penelitian

\begin{tabular}{llll}
\hline & & \multicolumn{2}{c}{$\begin{array}{c}\text { Model } \\
\text { Pembelajaran (A) }\end{array}$} \\
\cline { 3 - 4 } & & $\begin{array}{r}\text { IBL } \\
\left(\mathrm{A}_{1}\right)\end{array}$ & $\begin{array}{c}\text { POGIL } \\
\left(\mathrm{A}_{2}\right)\end{array}$ \\
\hline $\begin{array}{l}\text { Keteram- } \\
\text { pilan }\end{array}$ & $\begin{array}{l}\text { Keterampil } \\
\text { Proses }\end{array}$ & $\mathrm{A}_{1} \mathrm{~B}_{1}$ & $\mathrm{~A}_{2} \mathrm{~B}_{1}$ \\
an Proses & & \\
(B) & Tinggi (B $\left.\mathrm{B}_{1}\right)$ & & \\
& Keterampil & & \\
& $\begin{array}{l}\text { an Proses } \\
\text { Rendah }\end{array}$ & $\mathrm{A}_{1} \mathrm{~B}_{2}$ & $\mathrm{~A}_{2} \mathrm{~B}_{2}$ \\
& & \\
& $\left(\mathrm{~B}_{2}\right)$ & & \\
\hline
\end{tabular}

Keterangan :

A $\quad=$ Model Pembelajaran

$\mathrm{A}_{1}=$ Model Pembelajaran IBL (Inquiry

Based Learning)

$\mathrm{A}_{2}=$ Model Pembelajaran POGIL (Process Oriented Guided Inquiry Learning)

$\mathrm{B}=$ Keterampilan Proses

$\mathrm{B}_{1} \quad=$ Keterampilan Proses Tinggi

$\mathrm{B}_{2}=$ Keterampilan Proses Rendah

$A_{1} B_{1}=$ Penggunaan model IBL pada siswa dengan keterampilan proses tinggi

$A_{1} B_{2}=$ Penggunaan model IBL pada siswa dengan keterampilan proses rendah

$\mathrm{A}_{2} \mathrm{~B}_{1}=$ Penggunaan model POGIL pada siswa dengan keterampilan proses rendah

$\mathrm{A}_{2} \mathrm{~B}_{2}=$ Penggunaan model POGIL pada siswa dengan keterampilan proses tinggi

Populasi dalam penelitian ini adalah seluruh siswa kelas XI IPA SMA Negeri Kebakkramat Semester genap tahun pelajaran 2016/2017 yang berjumlah 5 kelas, yaitu XI IPA 1, XI IPA 2, XI IPA 3, XI IPA 4, dan XI IPA 5. Sampel terdiri dari 2 kelas yang diambil menggunakan teknik cluster random sampling.

Teknik pengumpulan data dalam penelitian ini yaitu tes tertulis, tes keterampilan proses, angket untuk penilaian afektif, dan observasi keterampilan praktikum untuk penilaian psikomotor. 
Siswa yang memiliki skor tes keterampilan proses di atas rata-rata digolongkan ke dalam tingkat keterampilan proses tinggi, sedangkan untuk siswa yang memiliki skor tes keterampilan proses dibawah rata-rata digolongkan ke dalam tingkat keterampilan proses rendah.

Sebelum eksperimen dilakukan, kelas eksperimen 1, kelas eksperimen 2, dan kelas uji coba instrumen diketahui keadaan awalnya. Hal tersebut dengan tujuan agar hasil eksperimen benar merupakan akibat dari perlakuan yang telah dibuat, bukan dikarenakan pengaruh lain. Untuk menguji keadaan awal kedua kelompok sampel digunakan uji kesetaraan rata-rata $t$ independent samples test (equal variances assumed) setelah terlebih dahulu diketahui bahwa populasi adalah homogeny. Uji normalitas yang digunakan adalah uji Kolmogorov Smirnov. Hipotesis penelitian ini diuji menggunakan statistik uji parametrik.

\section{HASIL DAN PEMBAHASAN}

Berikut disajikan nilai rata-rata pada model IBL dan POGIL di masing-masing aspek kognitif, afektif dan psikomotor seperti yang ditunjukkan pada Tabel 2

Tabel 2. Nilai Rata-Rata Prestasi Belajar Siswa

\begin{tabular}{lccc}
\hline & \multicolumn{3}{c}{ Nilai Rata-Rata } \\
\cline { 2 - 4 } & Kognitif & Afektif & Psikomotor \\
\hline IBL & 75,79 & 78,26 & 80,10 \\
POGIL & 80,00 & 73,05 & 80,68 \\
\hline
\end{tabular}

Berikut disajikan hasil uji hipotesis prestasi belajar aspek kognitif dapat dilihat pada Tabel 3, prestasi belajar aspek afektif dapat dilihat pada Tabel 4, dan prestasi belajar aspek psikomotor siswa dapat dilihat pada Tabel 5 .

Tabel 3. Hasil Uji Hipotesis Aspek Kognitif

\begin{tabular}{cccl}
\hline Hipotesis & Sig & $\begin{array}{c}\text { Taraf } \\
\text { Sig. }\end{array}$ & Keputusan \\
\hline 1 & 0,011 & 0,05 & H0 ditolak \\
2 & 0,944 & 0,05 & H0 diterima \\
3 & 0,211 & 0,05 & H0 diterima \\
\hline
\end{tabular}

Tabel 4. Hasil Uji Hipotesis Aspek Afektif

\begin{tabular}{cccl}
\hline Hipotesis & Sig & $\begin{array}{c}\text { Taraf } \\
\text { Sig. }\end{array}$ & Keputusan \\
\hline 1 & 0,025 & 0,05 & H0 ditolak \\
2 & 0,023 & 0,05 & H0 ditolak \\
3 & 0,440 & 0,05 & H0 diterima \\
\hline
\end{tabular}

Tabel 5. Hasil Uji Hipotesis Aspek Psikomotor

\begin{tabular}{cccl}
\hline Hipotesis & Sig & $\begin{array}{c}\text { Taraf } \\
\text { Sig. }\end{array}$ & Keputusan \\
\hline 1 & 0,663 & 0,05 & H0 diterima \\
2 & 0,003 & 0,05 & H0 ditolak \\
3 & 0,037 & 0,05 & H0 ditolak \\
\hline
\end{tabular}

\section{Hipotesis Pertama}

Terdapat perbedaan prestasi belajar siswa menggunakan model pembelajaran Inquiry Based Learning (IBL) dan Process Oriented Guided Inquiry Learning (POGIL) pada aspek kognitif dan afektif, tetapi tidak memberikan perbedaan pada aspek psikomotor.

Larutan penyangga merupakan salah satu materi kimia dikelas XI IPA yang sifatnya runtut, artinya materi satu dengan materi yang lainnya saling berhubungan. Materi prasyarat larutan penyangga adalah materi asam basa dan $\mathrm{pH}$. Materi tersebut bertindak sebagai pengetahuan awal yang dimiliki siswa untuk mampu menyelesaikan masalahmasalah yang berkaitan dengan larutan penyangga.

Melalui kegiatan praktikum pada kegiatan inti yang merupakan tahap eksplorasi dari kedua model pembelajaran IBL dan POGll. Pada model IBL, siswa diajak secara mandiri untuk menemukan pemahaman konsep yang menekankan pada proses penemuannya sehingga memungkinkan mereka menjadi pebelajar yang aktif [12].

Hal tersebut dapat dilihat pada sintaks IBL, dimana siswa merancang sendiri penelitian/eksperimen terkait materi pembelajaran. Pada model POGIL memiliki ciri yakni kegiatan pembelajaran dirancang secara khusus sehingga membuat siswa lebih aktif dalam penyelidikan, serta membuat siswa lebih terarah dalam pemecahan masalah 
sehingga menghasilkan konsep baru bagi siswa. Hal tersebut terlihat pada sintaks tahap eksplorasi.

Faktor lain yang ikut mempengaruhi perbedaan prestasi aspek kognitif pada model IBL dan POGIl antara lain adalah bantuan yang diberikan guru pada saat proses pembelajaran berlangsung. Pada pembelajaran model POGIL lebih banyak dibandingkan model pembelajaran IBL.

Aspek afektif mencakup watak perilaku seperti sikap, minat, konsep diri, nilai dan moral. Keaktifan siswa dalam proses pembelajaran juga mempengaruhi prestasi belajar ranah afektif sehingga mampu memberikan perbedaan pada prestasi belajar aspek afektif jika dilihat dari rata-rata.

Penelitian oleh Opera (2011) menyatakan bahwa model pembelajaran berbasis inkuiri memiliki efek positif terhadap minat dan sikap siswa dalam belajar. Dalam pembelajaran IBL siswa aktif menemukan sendiri pengetahuannya dengan melakukan praktikum maupun diskusi kegiatan tersebut dilakukan berdasarkan rasa keingin tahuan siswa terhadap permasalahan yang diberikan oleh guru.

Rasa ingin tahu tersebut meningkatkan motivasi siswa dalam belajar sehingga sikap siswa dalam pembelajaran juga ikut meningkat. Sedangkan menurut Hanson (2006) tahap eksplorasi pada pembelajaran POGIL, guru memberikan garis besar materi yang akan dipelajari dan pentingnya materi tersebut menyebabkan meningkatnya motivasi dan ketertarikan siswa dalam belajar [4]. Namun kenyataanya dilapangan berbeda, hal tersebut dapat disebabkan oleh karakteristik siswa itu sendiri, karena model pembelajaran bukan merupakan faktor internal terhadap keberhasilan prestasi belajar.

Tidak terdapatnya perbedaan pada aspek psikomotor dapat disebabkan karena kedua model tersebut sama-sama melatihkan siswa dalam melakukan percobaan di laboratorium. Selain itu, langkah kerja yang dilakukan di kedua model tersebutpun sama, sehingga hal tersebut menyebabkan tidak terdapatnya perbedaan model IBL dan POGIL terhadap prestasi belajar siswa aspek psikomotor.

Faktor lain yang menyebabkan tidak terdapatnya perbedaan prestasi belajar pada aspek psikomotor pada model IBL dan POGIl dikarenakan pada kedua model ini bertujuan untuk membantu siswa belajar dari masalah yang diberikan oleh guru serta membangun konsep sendiri. Selain itu karakteristik kedua kelas yang jarang melakukan praktikum dilaboratorium juga menjadi salah satu faktor penyebab tidak terdapatnya perbedaan antara model IBL dan POGIL pada aspek psikomotor.

\section{Hipotesis Kedua}

Terdapat perbedaan prestasi belajar siswa yang memiliki keterampilan proses tinggi dan keterampilan proses rendah pada aspek afektif dan psikomotor, tetapi tidak memberikan perbedaan pada aspek kognitif.

Keterampilan proses tidak memberikan perbedaan pada aspek kognitif. Hal tersebut dapat terjadi karena indikator-indikator dalam keterampilan proses tidak terwakili pada tes kognitif. Indikator pada keterampilan proses tersebut yang tidak terwakilkan seperti mengamati, membuat hipotesis, menafsirkan data dan melakukan percobaan. Hal tersebut didukung oleh penelitian Guritno (2015) keterampilan proses tidak berpengaruh pada prestasi belajar siswa aspek kognitif [14].

Aspek afektif merupakan salah satu bagian dari prestasi belajar siswa yang menyiratkan aspek kognitif dan psikomotor. Aspek afektif mencakup watak perilaku seperti sikap, minat, konsep diri, nilai dan moral. Terdapat perbedaan prestasi belajar aspek afektif pada siswa yang memiliki keterampilan proses tinggi dan rendah dapat dikarenakan ada beberapa indikator dalam keterampilan proses seperti mengkomunikasikan, memprediksi, melakukan percobaan terwakili dalam aspek afektif.

Siswa yang memiliki keterampilan proses tinggi cenderung akan memiliki rasa ingin tahu, minat, serta motivasi yang lebih tinggi terhadap materi yang sedang ia pelajari, akibatnya akan berdampak pada prestasi belajar aspek afektif, begitu 
pula sebaliknya, siswa dengan keterampilan proses rendah cenderung bermalas-malasan, pasif, tidak bersemangat, kurang aktif dalam mengikuti pelajaran, sehingga prestasi belajar aspek afektifnya pun rendah. Perbedaan itulah yang menjadi salah satu alasan dari terdapatnya perbedaan prestasi belajar aspek afektif pada siswa yang memiliki keterampilan proses tinggi maupun rendah.

Keterampilan proses tinggi dan rendah memberikan perbedaan pada prestasi belajar siswa aspek psikomotor, karena indikator didalam keterampilan proses terwakili dalam indikator aspek psikomotor. Hasil tersebut juga sejalan dengan penelitian Dwijono (2013) bahwa keterampilan proses sains baik tinggi dan rendah memberikan pengaruh serta perbedaan yang signifikan pada prestasi belajar aspek psikomotor [15].

\section{Hipotesis Ketiga}

Terdapat interaksi antara model pembelajaran Inquiry Based Learning (IBL) dan Process Oriented Guided Inquiry Learning (POGIL) dengan keterampilan proses terhadap prestasi belajar siswa aspek psikomotor, sedangkan aspek kognitif dan afektif tidak.

Faktor-faktor yang mempengaruhi keberhasilan prestasi belajar siswa antara lain faktor internal dan faktor eksternal. Faktor internal merupakan faktor yang berasal dari dalam diri siswa antara lain kemampuan siswa dan keterampilan proses, sedangkan faktor eksternal merupakan faktor yang berasal dari luar diri siswa antara lain pemilihan model. Pemilihan model harus disesuaikan dengan karakteristik peserta didik, materi dan sumber daya yang ada. Sedangkan keterampilan proses erat kaitannya dengan dengan kemampuan yang ada dalam diri siswa.

Keterampilan proses merupakan keterampilan yang digunakan untuk mempelajari sains. Siswa yang memiliki keterampilan proses akan mudah mempelajari dan memahami sains. Model pembelajaran berbasis inkuiri dalam hal ini Inquiry Based Learning (IBL) dan Process Oriented Guided Inquiry Learning (POGIL) merupakan model pembelajaran yang melibatkan siswa aktif didalam mengikuti pelajaran.

Kegiatan praktikum dan diskusi yang dilakukan baik di laboratorium maupun di ruang kelas pada model Inquiry Based Learning (IBL) dan Process Oriented Guided Inquiry Learning (POGIL) memudahkan siswa dalam membangun konsep materi larutan penyangga. Sehingga, siswa lebih mudah dalam memahami materi yang diajarkan melalui pelaksanaan percobaan. Siswa yang memiliki keterampilan proses tinggi tidak mengalami kendalam dalam melaksanakan pembelajaran model inkuiri. Siswa memiliki keterampilan dalam melakukan percobaan dan mengambil kesimpulan dari hasil percobaan. Hal ini berdampak pada aspek psikomotor siswa [14].

Terdapatnya interaksi antara model pembelajaran dan keterampilan proses memerlukan uji lanjut untuk mengetahui model dan keterampilan proses mana yang memberikan interaksi yang signifikan Uji lanjut untuk hipotesis ketiga pada penelitian ini, penulis menggunakan uji Scheffe. Berdasarkan hasil uji Scheffe pada ke semua kombinasi model dan keterampilan proses memiliki nilai Sig. > 0,05 yakni 0,037 .

Berdasarkan hasil tersebut, dapat disimpulkan bahwa interaksi antara model dan keterampilan proses tidak memberikan pengaruh yang signifikan terhadap prestasi belajar aspek psikomotor siswa. Terdapatnya interaksi antara model pembelajaran IBL dan POGIL dengan keterampilan proses terhadap prestasi belajar siswa pada psikomotor pada materi larutan penyangga dapat disebabkan siswa karena dalam dua model inkuiri yang menjadi objek penelitian sama-sama menggunakan laboratorium sebagai salah satu sarana dalam pembelajaran.

Tidak terdapatnya interaksi antara model pembelajaran IBL dan POGIL dengan keterampilan proses terhadap prestasi belajar siswa pada aspek kognitif pada materi larutan penyangga dapat disebabkan karena siswa belum terbiasa dan siap menerima model pembelajaran berbasis inkuiri. Padahal didalam model pembelajaran berbasis inkuiri, 
menyiratkan adanya keterampilan proses seperti mengamati, mengukur, menghitung, mengklasifikasi, membuat hipotesis, memprediksi, dan menyimpulkan.

Tidak terdapatnya interaksi antara model pembelajaran IBL dan POGIL dengan keterampilan proses terhadap prestasi belajar siswa pada afektif pada materi larutan penyangga dikarenakan pada siswa dengan keterampilan proses tinggi cenderung lebih aktif dalam mengikuti pelajaran dan merasa lebih termotivasi untuk membantu teman yang mengalami kesulitan dalam memahami dan membangun konsep materi larutan penyangga.

Banyak faktor yang dapat mempengaruhi proses pencapaian prestasi belajar baik dalam maupun luar siswa, diluar dari faktor model dan keterampilan proses yang digunakan dalam penelitian ini merupakan salah satu penyebab tidak terdapatnya interaksi antara keterampilan proses dengan model pembelajaran IBL dan POGIL, serta masih banyak keterbatasan dalam penelitian ini sehingga tidak dapat mengontrol faktorfaktor tersebut di luar kegiatan belajar mengajar. Penjelasan diatas didukung oleh Dwiono (2013) yang menyatakan bahwa tidak terdapatnya interaksi terhadap aspek afektif dapat disebabkan oleh faktor-faktor yang bukan menjadi faktor yang mempengaruhi prestasi belajar siswa dalam penelitian yakni model dan keterampilan proses [15].

\section{KESIMPULAN}

Kesimpulan dari hasil penelitian ini antara lain (1) Terdapat perbedaan prestasi belajar siswa menggunakan model pembelajaran Inquiry Based Learning (IBL) dan Process Oriented Guided Inquiry Learning (POGIL) pada aspek kognitif dan afektif, tetapi tidak memberikan perbedaan pada aspek psikomotor; (2) Terdapat perbedaan prestasi belajar siswa yang memiliki keterampilan proses tinggi dan keterampilan proses rendah pada aspek afektif dan psikomotor, tetapi tidak memberikan perbedaan pada aspek kognitif; (3) Terdapat interaksi antara model pembelajaran Inquiry Based Learning (IBL) dan Process Oriented Guided Inquiry Learning (POGIL) dengan keterampilan proses terhadap prestasi belajar siswa aspek psikomotor, sedangkan aspek kognitif dan afektif tidak.

\section{UCAPAN TERIMA KASIH}

Penulis menyadari dalam penelitian dan penyusunan skripsi ini banyak mendapatkan petunjuk dan bantuan dari berbagai pihak. Dengan segala kerendahan hati penulis mengucapkan terima kasih kepada: (1) Drs. Bambang Sugeng Maladi, M.M selaku Kepala SMA $\mathrm{N}$ Kebakkramat, (2) Kasirin, S.Pd.,M.Pd selaku guru mata pelajaran Kimia SMA N Kebakkramat.

\section{DAFTAR RUJUKAN}

[1] Siwa, I.B., Muderawan, I.W., \& Tika, I.N. (2013). E-Journal Program Pascasarjana Universitas Pendidikan Ganesha, 3, 1-13

[2] Ozgelen, S. (2012). Eurasia Journal of Mathematics, Science \& Technology Education. 8(4), 283292

[3] Wardani, S., Nurhayati, S., \& Safitri, A. (2016). International Journal of Science and Research (IJSR) Index Copernicus Value, (6), 1589-1593

[4] Hanson, D. (2006).Designing process Oriented Guided Inquiry Learning Activities. Faculty Development

[5] Marsita, R.A., Priatmoko. S, \& Kusuma E. (2010). Jurnal Inovasi Pendidikan Kimia, 4(1), 512-520

[6] Assriyanto, K.E., Sukardjo, J.S., \& Sulistyo, S. (2014). Jurnal Pendidikan Kimia, 3(3), 89-97

[7] Fajri, L., Ashadi. \& Utomo, S.B. (2015). Jurnal Inkuiri. 4(2), 10-18 
[8] Khawasi, A. \& Aisyah, L. (2009). Jurnal Pendidikan , 1, 92-108

[9] Sanjaya, W. (2006). Strategi Pembelajaran Berorientasi Standar Proses Pendidikan. Jakarta: Kencana Prenada Group.

[10] A'yun, D.Q., Sukarmin, \& Suparmi. (2015). Jurnal Inkuiri, 4(1), 1-10

[11] Kusmaryono, $\mathrm{H}$ \& Setiawati, $\mathrm{R}$. (2013). Jurnal Pendidikan Ekonomi Dinamika Pendidikan 7(2), 133-145
[12] Widyaningsih, S.Y., Haryono, \& Sulistyo, S. (2012). Jurnal Inkuiri, 1(3), 266-275

[13] Farola. (2013). Jurnal Pendidikan Teknik Elektro 2(2), 837-843.

[14] Guritno, T.A.M., Masykuri, M., \& Ashadi. (2015). Jurnal Inkuiri 4(2), 19.

[15] Dwijono, Widha, S. \& Sugiyarto. (2013). Jurnal Inkuiri 2(2), 124-133 